\title{
Four Achnanthidium species (Bacillariophyta) formerly identified as Achnanthidium minutissimum from the Antarctic Region
}

\author{
Bart VAN DE VIJVER ${ }^{1,2} \&$ Kateřina KOPALOVÁ ${ }^{3}$ \\ ${ }^{1}$ Botanic Garden Meise, Department of Bryophyta \& Thallophyta, \\ Nieuwelaan 38, B-1860 Meise, Belgium \\ Email: vandevijver@br.fgov.be (corresponding author) \\ ${ }^{2}$ University of Antwerp, Department of Biology, ECOBE, \\ Universiteitsplein 1, B-2610 Wilrijk, Antwerpen, Belgium \\ ${ }^{3}$ Charles University in Prague, Faculty of Science, Department of Ecology, \\ Viničná 7, CZ-12844 Prague 2, Czech Republic
}

\begin{abstract}
Four taxa belonging to the complex of species around Achnanthidium minutissimum were found during the ongoing taxonomic revision of the Antarctic freshwater and limno-terrestrial diatom flora. Two taxa were previously described as Achnanthidium lailae and A. sieminskae. Two others were formerly identified as $A$. minutissimum but detailed light and scanning electron microscopical observations revealed sufficient morphological differences compared to the type of A. minutissimum, to justify their separation and description as new taxa: Achnanthidium indistinctum and A. maritimo-antarcticum. The morphology and ecology of all four taxa are discussed comparing the species with morphologically similar taxa. The biogeographical consequences of the splitting of the former A. minutissimum complex in the Antarctic Region are discussed.
\end{abstract}

Keywords. Achnanthidium, Bacillariophyta, Antarctic Region, new species, biogeography.

Van de Vijver B. \& Kopalová K. 2014. Four Achnanthidium species (Bacillariophyta) formerly identified as Achnanthidium minutissimum from the Antarctic Region. European Journal of Taxonomy 79: 1-19. http://dx.doi. org/10.5852/ejt.2014.79

\section{Introduction}

Based on the list of all published diatom records (40 entries) from the Antarctic Region in Kellogg \& Kellogg (2002), Achnanthes minutissima Kütz. (Kützing 1833) is one of the most commonly observed diatom taxa in the (sub-)Antarctic Region. Apart from the Antarctic Continent, the species has been reported from all investigated localities on the sub-Antarctic Islands in the southern Indian Ocean (Bourrelly \& Manguin 1954; Le Cohu 2005; Van de Vijver et al. 2002) and the Maritime Antarctic Region (e.g., South Shetland Islands, South Orkney Islands) (Jones et al. 1993; Oppenheim 1994). The species often forms large populations on the sub-Antarctic islands, dominating the aquatic diatom communities in lakes and pools (Van de Vijver et al. 2001, 2002, 2004, 2008). All findings contributed to the generally accepted idea that $A$. minutissima was a typical cosmopolitan species showing a worldwide distribution on all continents (Ector 2011). 
The correct identity and biogeographical distribution of this taxon has for a long time been obscured by force-fitting and taxonomic drift. As a correct interpretation of the type of A. minutissima was virtually unknown, all identifications were based on the short description in Kützing (1833). In 1994, Czarnecki transferred the species to the genus Achnanthidium as Achnanthidium minutissimum (Kütz.) Czarnecki (Czarnecki 1994). The type material of Achnanthes minutissima remained unstudied until Potapova \& Hamilton (2007) published for the first time several SEM images from the type material. Following a taxonomic workshop in Luxemburg in 2009 (Ector 2011), it was clear that the old concept of A. minutissimum was no longer acceptable and that a revision of all populations formerly identified as A. minutissimum was necessary. A special volume of Algological Studies (published in 2011) describing the workshop results, was entirely dedicated to the study of the Achnanthidium minutissimum-complex. A large number of new taxa were described, split off from the former catch-all taxon A. minutissimum and some of its varieties. Since 2009, more than 15 new Achnanthidium species have been described such as A. caravelense Novais \& Ector (Novais et al. 2011), A. acerosum Van de Vijver, Lange-Bert. \& Jarlman (Van de Vijver et al. 2011a) and A. acsiae Wojtal, E.Morales, Van de Vijver \& Ector (Wojtal et al. 2011). Simultaneously to the revision of the European and North American Achnanthidium minutissimum complex, several Antarctic populations have been re-investigated which resulted in the separation of two new species with a purely Antarctic distribution. In 2009, Zidarova et al. described Achnanthidium lailae Van de Vijver (Zidarova et al. 2009) from James Ross Island located in the northern Weddell Sea, close to the Antarctic Peninsula. Three years later, Achnanthidium sieminskae Witkowski, Kulikovskiy \& Riaux-Gobin (Witkowski et al. 2012) was described from the sub-Antarctic Iles Kerguelen in the southern Indian Ocean.

During a survey of the freshwater diatom flora from the Maritime Antarctic Region, two other taxa have been found that were previously identified as A. minutissimum. Analysis of their ultrastructure using scanning electron microscopy revealed significant differences with the type of Achnanthidium minutissimum and with all other recently split-off taxa justifying their description as new taxa. The present paper gives a formal description for both new taxa, Achnanthidium maritimo-antarcticum sp. nov. and $A$. indistinctum sp. nov., and discusses the morphology, ecology and distribution of the two other Antarctic taxa, A. lailae and A. sieminskae.

\section{Material and methods}

Samples used in this study were collected during several field trips from different aquatic habitats on the South Shetland Islands (Livingston Island), James Ross Island and the sub-Antarctic Islands in the southern Indian (Iles Crozet, Iles Kerguelen, Prince Edward Islands) and Atlantic Ocean (South Georgia) (Fig. 1). Details on sampling methods and physico-chemical analyses can be found in Van de Vijver \& Beyens (1996), Van de Vijver et al. (2001, 2002, 2004, 2008), Kopalová et al. (2013) and Kopalová \& Van de Vijver (2013).

Diatom samples for LM observation were prepared following the method described in Van der Werff (1955). In total, ten sampling sites from various Antarctic localities were examined in this study, with all samples listed in Table 1. Subsamples of the original material were oxidized using $37 \% \mathrm{H}_{2} \mathrm{O}_{2}$ and heating to $80^{\circ} \mathrm{C}$ for approximately $1 \mathrm{~h}$. The reaction was further completed by the addition of KMnO4. Following digestion and centrifugation (three times 10 minutes at 3700x g), the material free of organic matter was diluted with distilled water for sample mounting to avoid excessive concentrations of diatom valves and frustules on the slides. A subsample from the organic-free material was mounted in Naphrax ${ }^{\circledR}$ for diatom community studies. The slides were analysed using an Olympus BX53 microscope, equipped with Differential Interference Contrast (Nomarski) and an Olympus UC30 digital camera. Samples and slides are stored at the BR-collection, property of the Belgian federal government and given in permanent loan to the Botanic Garden Meise (Belgium). For scanning electron microscopy (SEM), parts of the oxidized suspensions were filtered through a $1-\mu \mathrm{m}$ Isopore ${ }^{\mathrm{TM}}$ polycarbonate membrane 
VAN DE VIJVER B. \& KOPALOVÁ K., Achnanthidium minutissimum complex in the Antarctic

filter (Merck Millipore). The stubs were sputter-coated with a Gold-Palladium layer of $10 \mathrm{~nm}$ and studied in a ZEISS ULTRA SEM microscope at $3 \mathrm{kV}$ (Natural History Museum London, UK). Diatom terminology follows Ross et al. (1979), Round et al. (1990) and Potapova \& Hamilton (2007). For comparison, the following publications were consulted: Krammer \& Lange-Bertalot (1991), Kobayashi (1997), Potapova \& Ponader (2004), Ivanov \& Ector (2006), Potapova (2006), Monnier et al. (2007), Ponader \& Potapova (2007), Potapova \& Hamilton (2007), Zidarova et al. (2009), Hlúbiková et al. (2011), Morales et al. (2011), Van de Vijver et al. (2011a, 2011b) and Witkowski et al. (2012).

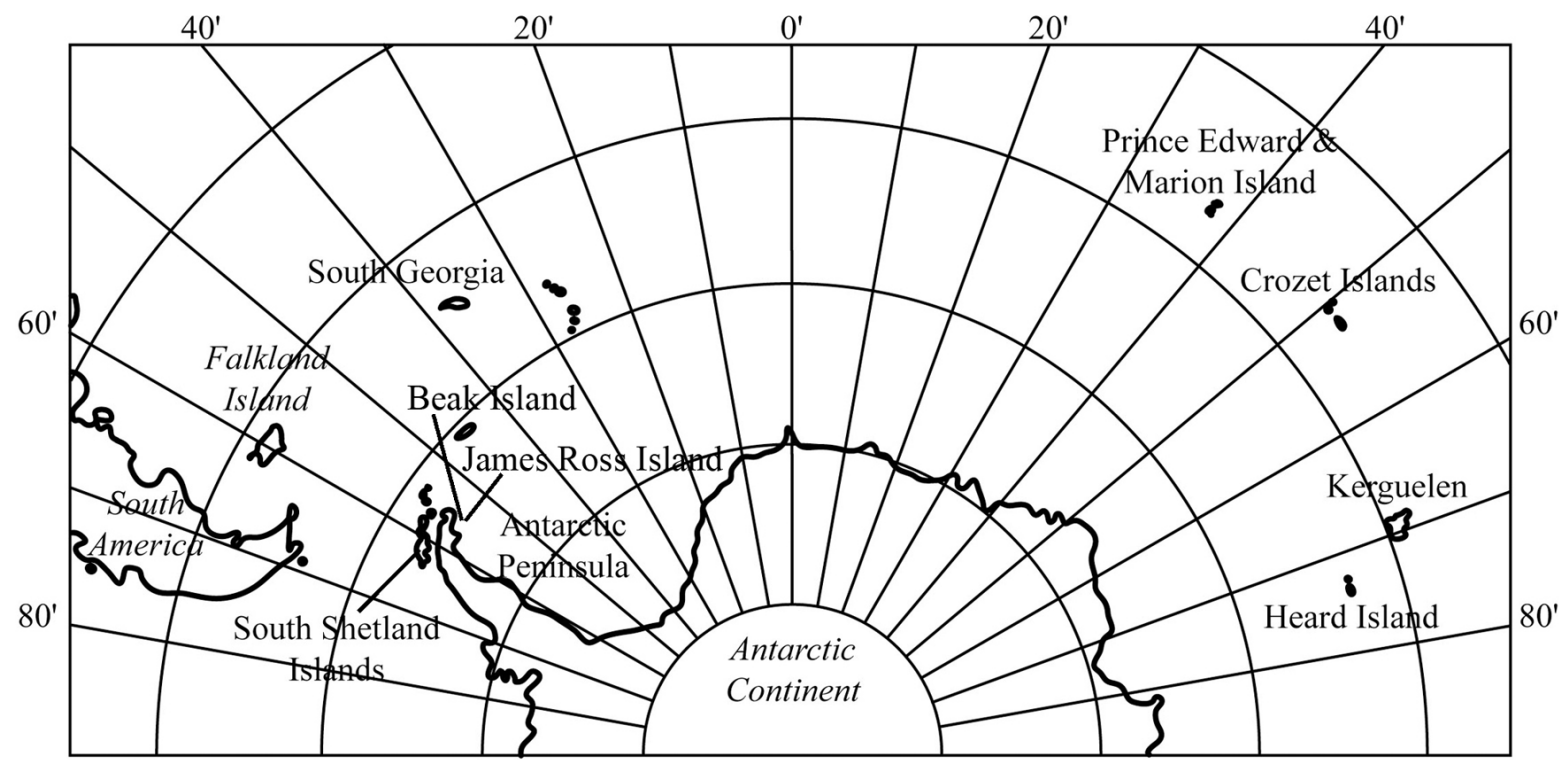

Fig. 1. The Antarctic region with the location of the sampled islands and archipelagos.

Table1. List of samples used in this study.

\begin{tabular}{|l|l|l|}
\hline Sample ID & Geographic locality & Source \\
\hline C-BW184 & Crozet & Van de Vijver et al. (2002) \\
\hline KER-POCO008 & Kerguelen & this study \\
\hline KER-BW417 & Kerguelen & Van de Vijver et al. (2001) \\
\hline He-D273 & Heard Island & Van de Vijver et al. (2004) \\
\hline PEI-D50 & Prince Edward Islands & Van de Vijver et al. (2008) \\
\hline SG-W398 & South Georgia & Van de Vijver \& Beyens (1996) \\
\hline LIV-BYM051 & Livingston Island & this study \\
\hline LIV-BY055 & Livingston Island & Kopalová \& Van de Vijver (2013) \\
\hline JRI2009-CLW58 & James Ross Island & this study \\
\hline JRI2009-CLW60 & James Ross Island & this study \\
\hline
\end{tabular}




\section{Results}

Class Bacillariophyceae Haeckel emend. Medlin \& Kaczmarska 2004 (Medlin \& Kaczmarska 2004)

Subclass Bacillariophycidae D.G.Mann in Round et al. 1990 (Round et al. 1990)

Order Achnanthales Silva 1962 (Silva 1962)

Family Achnanthidiaceae D.G.Mann in Round et al. 1990 (Round et al. 1990)

Genus Achnanthidium Kütz. 1844 (Kützing 1844)

Achnanthidium indistinctum Van de Vijver \& Kopalová sp. nov.

Figs 2-28

\section{Morphological observations}

\section{Light microscopy (Figs 2-24)}

Frustules short, rectangular in girdle view, bent around the transapical axis (Figs 2-4). Mantle striae often apparently thickened in LM (Fig. 4). Valves narrowly lanceolate with slightly to clearly convex margins and distinctly protracted, rostrate apices (Figs 2-24). Valve dimensions ( $\mathrm{n}=30$ ): length $8.5-13.0$ $\mu \mathrm{m}$, width 1.8-2.2 $\mu \mathrm{m}$. Raphe valve (Figs 5-15) concave with a very narrow linear axial area, almost invisible towards the valve apices, almost not widening towards the central part of the valve. Central area very small, indistinct, bordered by several (usually two) more widely spaced striae. Raphe straight, filiform, almost invisible, with simple proximal raphe endings. Distal raphe fissures not discernible in LM. Striae moderately radiate throughout the entire valve, becoming indiscernible (due to higher density) near the apices. Rapheless valve (Figs 16-24) slightly convex with narrow, linear axial area, not or very slightly widening towards the valve centre. Central area almost non-existing, never forming a fascia or subfascia. Central striae very weakly more distantly spaced. Striae weakly radiate throughout, only very slightly more densely spaced near the apices, $30-35$ in $10 \mu \mathrm{m}$.

\section{Scanning electron microscopy (Figs 25-28)}

Striae in the rapheless valve composed of a series of 3-4 distinct, rounded to square areolae (Fig. 25). Slit-like areolae apparently never present. Central striae less dense than in the rest of the valve (Fig. 25). Near the apices, striae only composed of 1-3 rounded areolae (Fig. 25). Mantle areolae elongated, slitlike, often enlarged (Fig. 25). Striae on the raphe valve, ca. 36 in $10 \mu \mathrm{m}$, composed of 2-3 irregularly shaped (mostly rounded or elongated rectangular) areolae (Fig. 26). Near the apices, stria density higher (up to 38 in $10 \mu \mathrm{m}$ ), composed of fewer areolae (Fig. 26). Internal areolae openings on both valves covered by hymenes (Figs 27,28). External raphe branches straight terminating in simple, short proximal raphe endings (Fig. 26). Distal raphe fissures straight, terminating just beyond the last apical stria (Fig. 26). Internally, proximal raphe endings shortly bent into opposite directions (Fig. 28). Distal raphe endings terminating in small helictoglossae (Fig. 28).

\section{Etymology}

The specific epithet was given because the species is rather small and can be easily overlooked.

\section{Type material}

\section{Holotype}

Slide BR-4361 (National Botanic Garden, Meise, Belgium).

\section{Isotypes}

Slides PLP-251 (UA, University of Antwerp, Belgium). 


\section{Type locality}

Byers Peninsula, Livingston Island, South Shetland Islands, sample BYM051 (62'38'20.1"S 61 $\left.{ }^{\circ} 06^{\prime} 44.2 ” W\right)$ (Leg. B. Van de Vijver; coll. date 15 Jan. 2009).

\section{Ecology, distribution and associated diatom flora}

So far, A. indistinctum has only been found on Livingston Island (South Shetland Islands). The type population was observed living on submerged mosses collected in a large lake on the central plateau, located between Midge Lake and Limnopolar lake. The lake had an alkaline $\mathrm{pH}$ (7.35) with a low specific conductance value $(97 \mu \mathrm{S} / \mathrm{cm})$ and a high phosphate level $(5.2 \mathrm{mg} / 1)$. The flora in the sample was
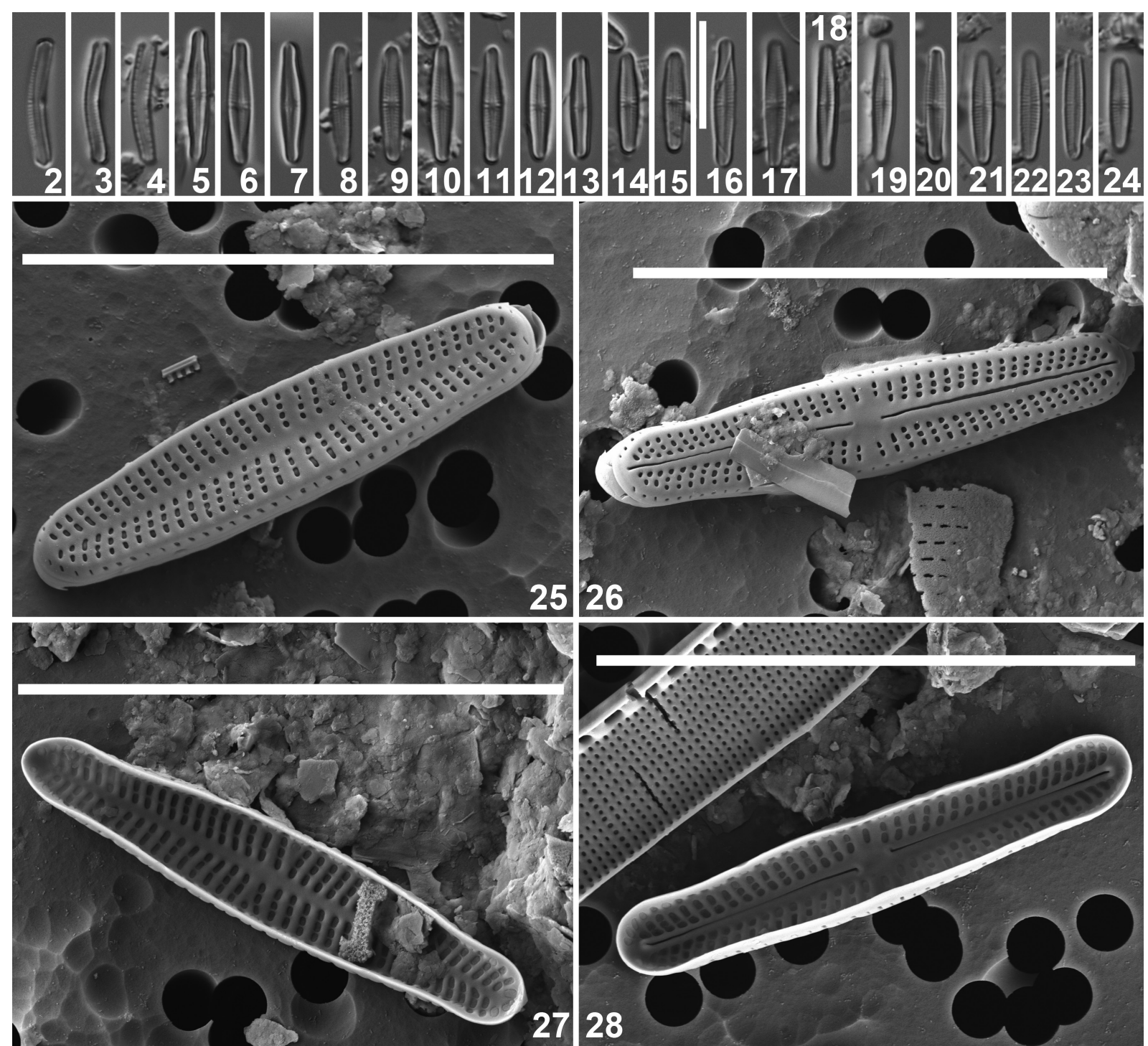

Figs 2-28. Achnanthidium indistinctum Van de Vijver \& Kopalová sp. nov. Light and scanning electron micrographs of the type population on Byers Peninsula (Livingston Island). 2-4. LM views of some frustules in girdle view. 5-15. LM views of raphe valves. 16-24. LM views of rapheless valves. 25. SEM external view of an entire rapheless valve. 26. SEM external view of an entire raphe valve. 27. SEM internal view of an entire rapheless valve. 28. SEM internal view of an entire raphe valve. Scale bars represent $10 \mu \mathrm{m}$. 
dominated by several Psammothidium species [P. abundans (Manguin) Bukht. \& Round (Bukhtiyarova \& Round 1996), P. papilio (D.E. Kellogg, M. Stuiver, T.B. Kellogg \& G.H. Denton) Van de Vijver \& Kopalová (Kopalová et al. 2012), P. subatomoides (Hust.) Bukht. \& Round (Bukhtiyarova \& Round 1996)], Nitzschia cf. perminuta (Grunow) M.Peragallo (Peragallo 1903), Brachysira minor (Krasske) Lange-Bert. in Lange-Bertalot \& Moser (Lange-Bertalot \& Moser 1994), Sellaphora seminulum (Grunow) D.G.Mann (Mann 1989) and Amphora sp. It is possible that the species is also present on Signy Island (South Orkney Islands) based on the illustrations in Oppenheim (1994). The distribution in the Antarctic region and other geographical areas is unclear due to the insufficient discrimination between species in the Achnanthidium minutissimum-complex. All published records should be verified in order to know the exact biogeography of this and all other taxa.

Achnanthidium maritimo-antarcticum Van de Vijver \& Kopalová sp. nov.

Figs 29-53

\section{Morphological observations}

\section{Light microscopy (Figs 29-49)}

Frustules in girdle view rectangular, bent around the transapical axis (Figs 29,30). Valves linear-lanceolate with parallel to slightly convex margins and clearly protracted, rostrate, occasionally subcapitate apices (Figs 31-49). Valve dimensions ( $\mathrm{n}=25$ ): length $12-15 \mu \mathrm{m}$, width 2.3-2.7 $\mu \mathrm{m}$. Raphe valve (Figs 31-40) concave with a linear axial area, narrow to almost absent near the valve apices, hardly widening towards the central part of the valve. Central area irregular, formed by several more widely spaced striae. Raphe straight, filiform, invisible, with indistinct straight, simple proximal raphe endings. Distal raphe hardly discernible in LM. Striae slightly radiate throughout the entire valve, becoming more radiate and more densely spaced near the apices, 30-33 in $10 \mu \mathrm{m}$, up to 40-42 in $10 \mu \mathrm{m}$ near the valve apices. Rapheless valve (Figs 41-49) slightly convex with very narrow, linear axial area, widening to form a weakly elliptically, never transapically elongated central area, never forming a fascia or subfascia. Central striae slightly more distantly spaced. Striae slightly radiate throughout, only slightly more denser near the apices, 30-32 in $10 \mu \mathrm{m}$.

\section{Scanning electron microscopy (Figs 50-53)}

Striae in the raphe valve composed of a series of 3-4 distinct, rounded to square areolae terminating in one transapically elongated, rectangular areola (Fig. 50). Central striae composed of 2 rounded areolae and one transapically elongated areola near the valve margin (Fig. 50). Occasionally, short slit-like areolae interposed between the central striae. Near the apices, striae only composed of 2-3 rounded areolae (Fig. 50). Mantle areolae elongated, slit-like. Striae on the rapheless valve composed of 2-5 irregularly shaped (mostly rounded or elongated rectangular) areolae (Fig. 51). Near the apices, striae showing lowest number of areolae (Fig. 51). Internal areolae openings on both valves covered by hymenes (Figs 52, 53). External raphe branches straight to weakly curved terminating in simple, short proximal and distal raphe endings (Fig. 50). Distal raphe endings terminating just beyond the last apical stria (Fig. 50). Internally, proximal raphe endings short, slightly bent. Distal raphe endings terminating in small helictoglossae (Fig. 52).

\section{Etymology}

The specific epithet refers to the geographical area where the new species was found: Maritime Antarctic Region. The hyphen can and should be maintained in the species name based on art. 60.9 of the International Code of Nomenclature for algae, fungi and plants (McNeill et al. 2012). 


\section{VAN DE VIJVER B. \& KOPALOVÁ K., Achnanthidium minutissimum complex in the Antarctic}

\section{Type material}

\section{Holotype}

Slide BR-4362 (National Botanic Garden, Meise, Belgium).

\section{Isotypes}

Slides PLP-252 (UA, University of Antwerp, Belgium).

\section{Type locality}

Byers Peninsula, Livingston Island, South Shetland Islands, sample BY055 (62³7'41.7''S 6106’30.4’W) (Leg. B. Van de Vijver; coll. date 15 Jan. 2009).
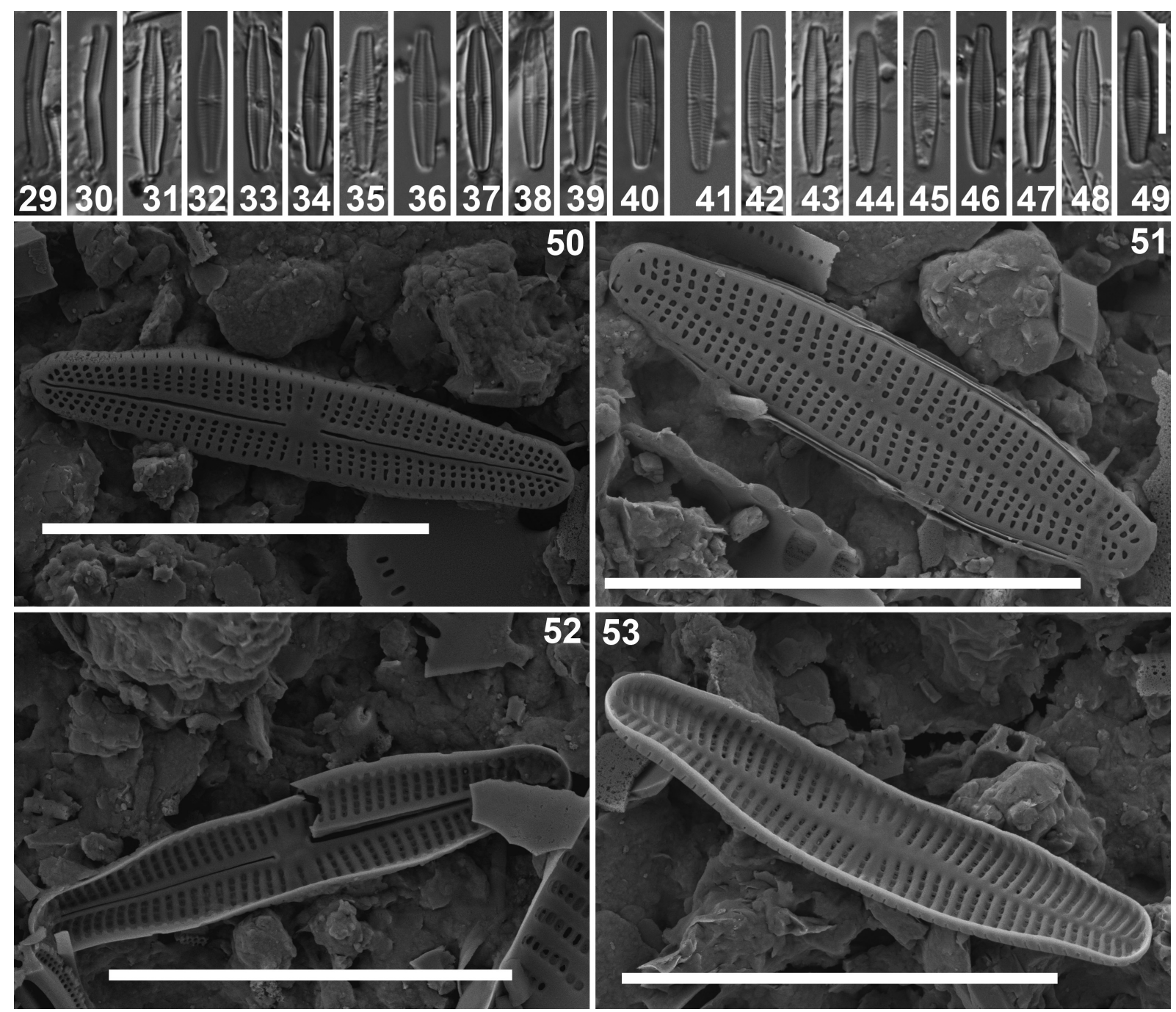

Figs 29-53. Achnanthidium maritimo-antarcticum Van de Vijver \& Kopalová sp. nov. Light and scanning electron micrographs of the type population on Byers Peninsula (Livingston Island). 29-30. LM views of some frustules in girdle view. 31-40. LM views of raphe valves. 41-49. LM views of rapheless valves. 50. SEM external view of an entire raphe valve. 51. SEM external view of an entire rapheless valve. 52. SEM internal view of an entire raphe valve. 53. SEM internal view of an entire rapheless valve. Scale bars represent $10 \mu \mathrm{m}$. 


\section{Ecology, distribution and associated diatom flora}

The type population of $A$. maritimo-antarcticum was found in a large lake located on the central plateau of Byers Peninsula. The lake is characterized by a weakly alkaline $\mathrm{pH}$ (7.5) and a low conductivity $(130 \mu \mathrm{S} / \mathrm{cm})$. The ion composition in the lake is mainly dominated by $\mathrm{Na}^{+}(20.0 \mathrm{mg} / \mathrm{l})$ and $\mathrm{Ca}^{2+}$ $(12.1 \mathrm{mg} / \mathrm{l})$. Both nutrients $\left(\mathrm{N}-\mathrm{NO}_{3}+\mathrm{N}-\mathrm{NO}_{2}\right)$ and phosphate were rather low $(25 \mu \mathrm{g} / \mathrm{l}$ and $10 \mu \mathrm{g} / \mathrm{l}$ resp.). The shoreline of the lake was completely covered with partly submerged mosses. Dominant taxa in the sample included Fragilaria capucina s.l. Desm. (Desmazières 1825), Staurosirella sp., Navicula cremeri Van de Vijver \& Zidarova in Van de Vijver et al. (Van de Vijver et al. 2011d) and Nitzschia cf. perminuta. Smaller populations were found in other lakes such as Limnopolar Lake but these populations never exceed $1 \%$ of the total diatom composition. Due to force-fitting and taxonomic drift, the distribution of the new taxon in the Antarctic Region is unclear.

Achnanthidium lailae Van de Vijver in Zidarova et al. (Zidarova et al. 2009)

Figs 54-77

\section{Morphological observations}

\section{Light microscopy (Figs 54-74)}

Frustules in girdle view narrow, rectangular, bent around the transapical axis, apices weakly recurved (Figs 54-56).Valves linear to very slightly linear-lanceolate with almost parallel margins and nonprotracted, broadly rounded, never rostrate or capitate apices (Figs 57-74). Valve dimensions $(n=30)$ : length $10-14 \mu \mathrm{m}$, valve width $1.8-2.5 \mu \mathrm{m}$. Raphe valve (Figs 57-64) concave with a rather narrow, linear to linear-lanceolate axial area, widening towards the central area. Central area forming a typical rectangular fascia. Shortened marginal striae occasionally present in the central area. Raphe straight to weakly undulating with inconspicuous straight proximal raphe endings. Distal raphe fissures not discernible in LM. Striae weakly but still distinctly radiate near the valve center, becoming more radiate near the apices, 30-33 in $10 \mu \mathrm{m}$. Rapheless valve (Figs 65-74) slightly convex with moderately broad, clearly lanceolate axial area, widening near the valve centre. Central area elongated, rhombic lanceolate, never expanding into a fascia due to several longer marginal striae in the central area. Striae parallel to weakly radiate near the valve centre, more radiate near the apices, 28-30 in $10 \mu \mathrm{m}$.

\section{Scanning electron microscopy (Figs 75-77)}

Striae on the raphe valve composed of 2-3 small areolae (Fig. 77). Areolae close to the axial area and at the apices rounded. Marginal areolae sometimes narrow, transapically elongated and hence slit-like, sometimes fused with the second areola (Fig. 77). Striae of the rapheless valve composed of 2-3 rounded to slit-like external areola openings (Fig. 75). Mantle areolae slit-like. Internal areolae openings covered by hymenes (Figs 76,77 ). When removed due to sample preparation, very narrow struts visible separating the areolae (Fig. 76). Raphe slightly undulating becoming narrower towards the apices (Fig. 77). Proximal raphe endings almost straight, inconspicuous. Distal raphe fissures weakly deflected, continuing slightly beyond the last striae, never onto the mantle (Fig. 77). Internally, proximal raphe endings shortly bent into opposite directions, terminating in a thickened central pore (Fig. 77). Distal raphe endings terminating on small helictoglossae.

\section{Ecology, distribution and associated diatom flora}

The type population was found in a large circumneutral lake $(\mathrm{pH}=7.1)$ on Ulu Peninsula on James Ross Island (Zidarova et al. 2009). Since then, several other large populations were discovered in lakes on Clearwater Mesa, a volcanic tableland on James Ross Island next to Ulu Peninsula. All populations were observed in alkaline lakes ( $\mathrm{pH} 8.1-8.7)$ with relatively high conductivity (1000-2000 $\mu \mathrm{S} / \mathrm{cm}$ ). The samples were dominated by Halamphora sp., Pinnularia australomicrostauron Zidarova et al. (Zidarova et al. 2012), Nitzschia cf. commutata Grunow in Cleve \& Grunow, and Achnanthes coarctata (Bréb.) 
Grunow in Cleve \& Grunow (Cleve \& Grunow 1880) and Gomphonema sp. So far, no populations were found on other islands in the Maritime Antarctic Region (Kopalová \& Van de Vijver 2013, Van de Vijver et al. unpubl. res.).

Achnanthidium sieminskae Witkowski, Kulikovskiy \& Riaux-Gobin (Witkowski et al. 2012)

Figs 78-103

\section{Morphological observations}

\section{Light microscopy (Figs 78-99)}

Frustules in girdle view rectangular, clearly bent around the transapical axis and with clearly recurved apices (Figs 78-80). Valves linear to narrowly linear-lanceolate with almost parallel to slightly convex
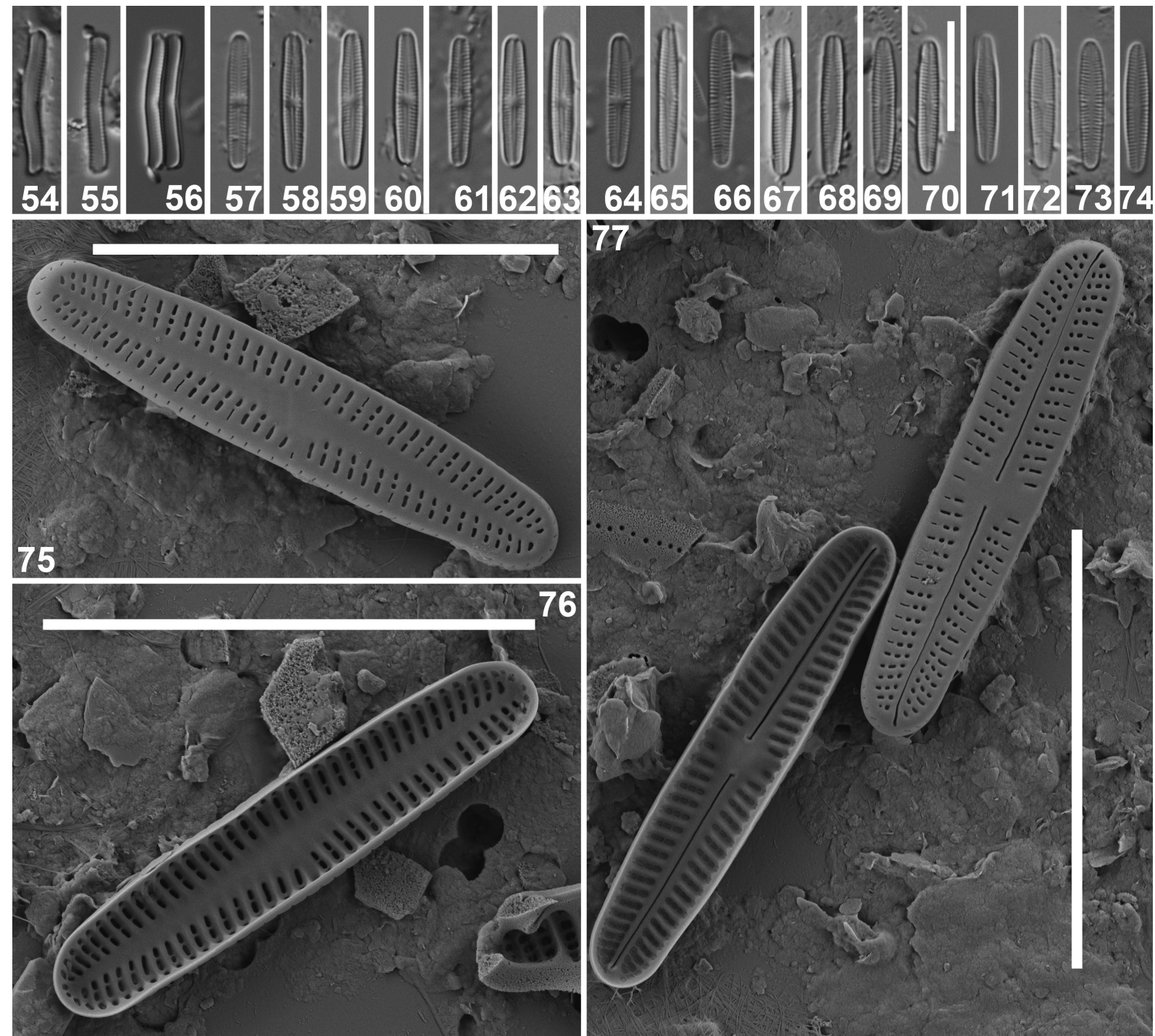

Figs 54-77. Achnanthidium lailae Van de Vijver. Light and scanning electron micrographs of a population on Clearwater Mesa (James Ross Island). 54-56. LM views of some frustules in girdle view. 57-64. LM views of raphe valves. 65-74. LM views of rapheless valves. 75. SEM external view of an entire rapheless valve. 76. SEM internal view of an entire rapheless valve. 77. SEM external (right) and internal (left) view of an entire raphe valve. Scale bars represent $10 \mu \mathrm{m}$. 
margins and clearly protracted, rostrate to even capitate apices (Figs 81-99). Valve dimensions ( $\mathrm{n}=25)$ : length 9.5-18.0 $\mu \mathrm{m}$, width 1.9-3.1 $\mu \mathrm{m}$. Raphe valve (Figs 81-91) concave with a very narrow linear axial area, almost not discernible near the valve apices. Central area elliptical to rounded, very small, almost indistinct, formed by 2-3 more widely spaced striae. Central striae often lacking extending the central area up to the valve margin. Raphe straight, filiform with simple, straight proximal raphe endings. Distal raphe hardly discernible in LM. Striae weakly radiate near the valve center, becoming parallel and even convergent near the apices, well visible in LM, ca. 32 in $10 \mu \mathrm{m}$, more densely spaced near the valve ends. Rapheless valve (Figs 92-99) slightly convex with narrow, linear axial area, widening to form a weakly elliptically, never transapically elongated central area. Fascia never present. Central 2-3 striae more distantly spaced. Striae weakly radiate throughout, becoming more parallel to even convergent near the apices, ca. 35 in $10 \mu \mathrm{m}$.
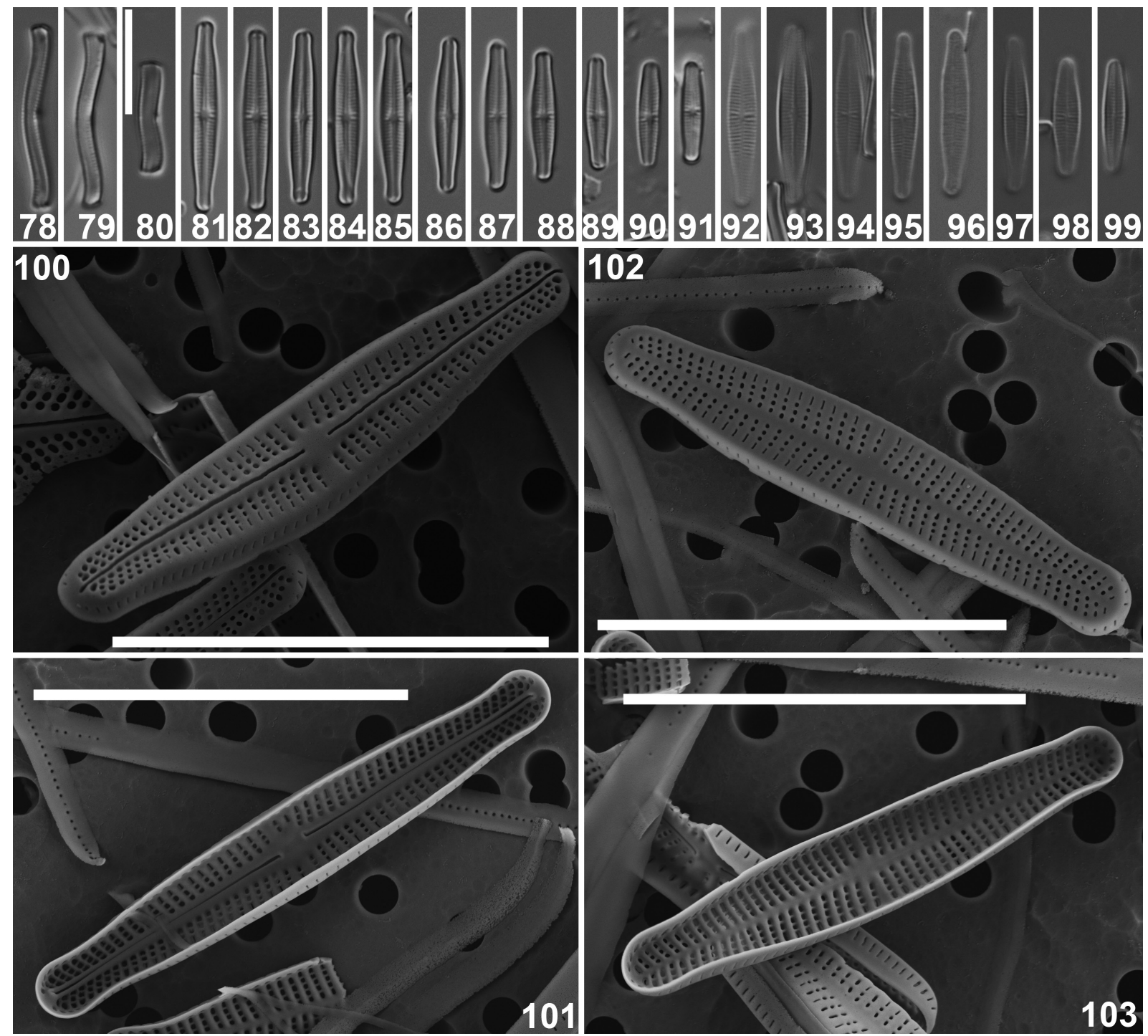

Figs 78-103. Achnanthidium sieminskae Witkowski, Kulikovskiy \& Riaux-Gobin. Light and scanning electron micrographs of a population on Iles Kerguelen. 78-80. LM views of some frustules in girdle view. 81-91. LM views of raphe valves. 92-99. LM views of rapheless valves. 100. SEM external view of an entire raphe valve. 101. SEM internal view of an entire raphe valve. 102. SEM external view of an entire rapheless valve. 103. SEM internal view of an entire rapheless valve. Scale bars represent $10 \mu \mathrm{m}$. 


\section{Scanning electron microscopy (Figs 100-103)}

Valve face of the raphe valve clearly concave. Valve face/mantle margin forming a weakly raised hyaline border separating valve face striae from mantle areolae. Striae, ca. 32-34 in 10 $\mu \mathrm{m}$, composed of 2-3 small, rounded areolae (Fig. 100) followed near the valve center by a thin, slit-like, marginal areola (Fig. 100). Near the apices, striae more dense, ca. 40 in $10 \mu \mathrm{m}$, composed of only 3 rounded areolae. Mantle areolae slit-like (Figs 100, 102). Raphe almost straight with simple, straight proximal raphe endings (Fig. 100). Distal raphe fissures weakly deflected, continuing slightly beyond the last striae terminating on the valve face/mantle junction. Internally, proximal raphe endings shortly bent into opposite directions(Fig. 101). Distal raphe endings terminating in small helictoglossae (Fig. 101). Internal areolae openings covered by hymenes (Fig. 101). Striae of the rapheless valve almost equally spaced throughout the entire valve, 34-36 in $10 \mu \mathrm{m}$, composed of 2-5 rounded areolae sometimes terminating in one slit-like areola (Fig. 102). Mantle areolae slit-like. Internal areolae openings covered by hymenes (Fig. 103).

\section{Ecology, distribution and associated diatom flora}

Achnanthidium sieminskae was originally described as a brackish-littoral taxon from a tidal flat near the Kerguelen Islands (Witkowski et al. 2012) but the authors already expressed some doubts about this observation. Most likely, their population was the result of a riverine deposition in the marine Bossière fjord on Kerguelen. As they stated themselves, the only way to find out would be the analysis of the living material which was unfortunately no longer available at the time of their publication. We reported this taxon (as A. minutissimum) from a large number of purely freshwater habitats ranging from small pools to larger lakes and even streams from all sub-Antarctic islands in both the Indian and Atlantic Ocean (Van de Vijver \& Beyens 1996; Van de Vijver et al. 2001, 2002, 2004, 2008). In many cases, very large populations could be observed, occasionally up to $60-80 \%$ of all counted valves. These data indicate that this is typical limno-terrestrial taxon preferring wet moss vegetations in pools, bogponds and lakes with a pH between 5.2 and 7.4 and a low conductivity $(<160 \mu \mathrm{S} / \mathrm{cm})$. These data confirm the final conclusion in Witkowski et al. (2012) that the observed valves in their study are the result of the redeposition of a freshwater species in a marine environment. Given the large amount of available data and material, it is a pity the original authors did not verify their rather unusual observation more carefully.

\section{Discussion}

All taxa discussed here clearly belong to the complex of species around Achnanthidium minutissimum based on the simple, straight distal raphe endings contrary to the species in the A. pyrenaicum group that have clearly deflected to even hooked distal raphe fissures (Kobayashi 1997; Potapova \& Hamilton 2007). In the (even recent) past, all taxa discussed were identified as Achnanthidium minutissimum (e.g., Oppenheim 1994; Van de Vijver et al. 2002; Le Cohu 2005; Kopalová \& Van de Vijver 2013). Table 2 summarizes all important morphological features of all four taxa formerly identified as A. minutissimum. The application of a more fine-grained taxonomy based on a narrow species concept (Mann 1999), the detailed analysis of type material of so-called cosmopolitan taxa and as a consequence no longer force-fitting (Tyler 1996) and taxonomic drift, clearly influenced our understanding of the biogeography of Antarctic diatoms as shown in the taxonomic revision of several genera such as Muelleria (Van de Vijver et al. 2010), Luticola (Van de Vijver \& Mataloni 2008, Van de Vijver et al. 2011c), Hantzschia (Zidarova et al. 2010) and Navicula (Van de Vijver et al. 2011d). A similar conclusion can now be made for the genus Achnanthidium confirming once more the unique nature of the Antarctic diatom flora and contradicting the Ubiquity hypothesis (Finlay \& Clarke 1999) stating the cosmopolitan nature of all micro-organisms. As a consequence, the genus Achnanthidium shows some interesting biogeographical aspects. At present, only six Achnanthidium taxa are known from the Antarctic Region. Apart from the four taxa discussed in this paper, two other Achnanthidium taxa, Achnanthidium modestiforme (Lange- 
Table 2. Overview of the main morphological features of all four taxa formerly identified as $A$. minutissimum s.l. reported from the Antarctic Region.

\begin{tabular}{|c|c|c|c|c|}
\hline & A. indistinctum & $\begin{array}{l}\text { A. maritimo- } \\
\text { antarcticum }\end{array}$ & A. lailae & A. sieminskae \\
\hline Valve length $(\mu \mathrm{m})$ & $8.5-13$ & $12-15$ & $10-14$ & $9.5-18$ \\
\hline Valve width $(\mu \mathrm{m})$ & $1.8-2.2$ & $2.3-2.7$ & $1.8-2.5$ & $1.9-3.1$ \\
\hline valve outline & narrowly lanceolate & linear-lanceolate & $\begin{array}{l}\text { linear to very } \\
\text { slightly linear- } \\
\text { lanceolate }\end{array}$ & $\begin{array}{l}\text { linear to narrowly } \\
\text { linear-lanceolate }\end{array}$ \\
\hline apices & $\begin{array}{c}\text { distinctly } \\
\text { protracted, rostrate }\end{array}$ & $\begin{array}{c}\text { clearly protracted, } \\
\text { rostrate, } \\
\text { occasionally } \\
\text { subcapitate }\end{array}$ & $\begin{array}{l}\text { non-protracted, } \\
\text { broadly rounded, } \\
\text { never rostrate or } \\
\text { capitate }\end{array}$ & $\begin{array}{l}\text { clearly protracted, } \\
\text { rostrate to even } \\
\text { capitate }\end{array}$ \\
\hline \multicolumn{5}{|c|}{ Rapheless valve } \\
\hline \# striae in $10 \mu \mathrm{m}$ & $30-35$ & $30-32$ & $28-30$ & ca. 35 \\
\hline \# areolae per stria & $\begin{array}{l}3-4, \text { rounded to } \\
\text { rectangular }\end{array}$ & $\begin{array}{l}2-5, \text { irregularly } \\
\text { shaped }\end{array}$ & $\begin{array}{l}2-3, \text { rounded to } \\
\text { slit-like }\end{array}$ & $\begin{array}{c}2-5, \text { rounded }+ \\
\text { sometimes } 1 \text { slit-like }\end{array}$ \\
\hline striation pattern & $\begin{array}{l}\text { slightly radiate } \\
\text { throughout }\end{array}$ & $\begin{array}{l}\text { slightly radiate } \\
\text { throughout }\end{array}$ & $\begin{array}{l}\text { parallel to weakly } \\
\text { radiate near the } \\
\text { valve centre, more } \\
\text { radiate near the } \\
\text { apices }\end{array}$ & $\begin{array}{c}\text { Striae weakly radiate } \\
\text { throughout, becoming } \\
\text { more parallel to even } \\
\text { convergent near the } \\
\text { apices }\end{array}$ \\
\hline \multicolumn{5}{|c|}{ Raphe valve } \\
\hline \# striae in $10 \mu \mathrm{m}$ & ca. 36 & $\begin{array}{l}30-33 \text {, up to } \\
40-42 \text { near the } \\
\text { valve apices }\end{array}$ & $30-33$ & ca. $32-34$ \\
\hline \# areolae per stria & $2-3$ & $2-3$, rounded & $2-3$, small & $\begin{array}{c}2-3, \text { small, rounded, }+ \\
\text { near the valve center } \\
1 \text { slit-like }\end{array}$ \\
\hline striation pattern & $\begin{array}{l}\text { moderately radiate } \\
\text { throughoout }\end{array}$ & $\begin{array}{l}\text { slightly radiate } \\
\text { throughout, more } \\
\text { radiate towards } \\
\text { the apices }\end{array}$ & $\begin{array}{l}\text { weakly but still } \\
\text { distinctly radiate } \\
\text { near the valve } \\
\text { center, becoming } \\
\text { more radiate near } \\
\text { the apices }\end{array}$ & $\begin{array}{l}\text { weakly radiate near } \\
\text { the valve center, } \\
\text { becoming parallel } \\
\text { and even convergent } \\
\text { near the apices }\end{array}$ \\
\hline $\begin{array}{l}\text { (sub-)Antarctic } \\
\text { distribution }\end{array}$ & $\begin{array}{l}\text { South Shetland } \\
\text { Islands }\end{array}$ & $\begin{array}{l}\text { South Shetland } \\
\text { Islands }\end{array}$ & James Ross Island & $\begin{array}{l}\text { South Georgia, Prince } \\
\text { Edward Islands, } \\
\text { Iles Crozet, Iles } \\
\text { Kerguelen, Heard } \\
\text { Island } \\
\end{array}$ \\
\hline
\end{tabular}


Bert.) Van de Vijver in Van de Vijver et al. (Van de Vijver et al. 2002) and A. australexiguum Van de Vijver in Taylor et al. (Taylor et al. 2014), a taxon recently described in the complex of species around A. exiguum (Grunow) Czarnecki (Czarnecki 1994), were confirmed from the Region. All six taxa are so far exclusively found in the Antarctic Region despite records of A. modestiforme from Argentina, Bolivia, Brazil and Chile (Maidana 1996; Díaz Villanueva \& Maidana 1999; Rumrich et al. 2000; Tremarin et al. 2009; Morales et al. 2011) that are clear examples of force-fitting and most likely represent other, yet undescribed taxa. Two of these six taxa have a distribution that is at present only restricted to the subAntarctic Region (including all islands and archipelagos in the southern Indian Ocean and South Georgia in the southern Atlantic Ocean): A. sieminskae and A. modestiforme, lacking at present any confirmed records from other parts of the Antarctic Region. On the other hand, the Maritime Antarctic Region counts four Achnanthidium taxa (A. lailae, A. maritimo-antarcticum sp. nov., A. indistinctum sp. nov. and $A$. australexiguum), all of which so far never observed outside this Region. It is however unclear whether this biogeography represents the complete distribution of these taxa or is just the consequence of undersampling and underreporting. Kellogg \& Kellogg (2002) list almost 40 records of Achnanthidium minutissimum (usually as Achnanthes minutissima) from mostly the Maritime Antarctic Region. All records should be verified to complete our biogeographical knowledge of the species discussed in this paper. Most literature records lack however (good) illustrations and even the retrieval of the original material is not always very straightforward making new sampling in these areas a more obvious choice to clarify the biogeography of these taxa.

Although molecular data would be interesting to confirm the separation of the taxa of the A. minutissimum complex, it is clear that all taxa discussed here are morphologically distinct from each other andare not conspecific with the former catch-all taxon A. minutissimum. Potapova \& Hamilton (2007) already presented some SEM images of the type material of $A$. minutissimum s.s. Based on these published images and additional (but so far unpublished) observations on the type material of A. minutissimum (Novais et al. submitted), it is clear that none of the observed populations in the Antarctic Region represent $A$. minutissimum s.s.

Achnanthidium indistinctum can be separated from A. minutissimum based on several features (Potapova \& Hamilton 2007; Hlúbiková et al. 2011). Morphometrically, A. indistinctum has clearly narrower valves (1.8-2.2 $\mu \mathrm{m}$ vs. 2.5-3.1 $\mu \mathrm{m}$ in A. minutissimum). Additionally, A. minutissimum has a higher number of areolae per stria, usually 4-5 (Novais et al. submitted), a high number never observed in A. indistinctum where 2-3(-4) is the rule. The mantle areolae in A. indistinctum are often enlarged making them easily visible in LM on frustules in girdle view, similarly to for instance $A$. hoffmannii Van de Vijver et al. (Van de Vijver et al. 2011a). Finally, the valve outline of A. minutissimum shows a combination of more convex valve margins together with clearly rostrate to subcapitate apices, compared to the weakly compared convex margins and weakly rostrate margins in A. indistinctum.

The second new taxon, A. maritimo-antarcticum can be separated from all other Achnanthidium taxa by its more linear valve outline in combination with the protracted, broadly rounded apices. The striae are solely composed of rounded to transapically elongated areolae, never presenting slit-like areolae as often found in several Achnanthidium taxa such as A. hoffmannii, A. minutissimum and A. lailae.

Zidarova et al. (2009) already discussed the differences between A. lailae, A. minutissimum and several other narrow, linear Achnanthidium taxa such as A. strictum Reichardt (Reichardt 2004) and A. lineare W.Sm. (Smith 1855). The analysis of additional populations of $A$. lailae on Clearwater Mesa, James Ross Island, confirm entirely the original separation of this taxon from the above mentioned taxa A. minutissimum, A. strictum and A. lineare, based on the weakly deflected distal raphe fissures and the higher number of areolae per stria in A. lailae. The only feature that need to be adjusted compared 
to the original description, is the presence of slit-like areolae near the valve margins. In the original description, the absence of these slit-like areolae was mentioned (Zidarova et al. 2009).

Our observations on the often very large freshwater populations of Achnanthidium sieminskae from Iles Kerguelen refine our knowledge on the morphology of this species. According to the original description (Witkowski et al. 2012), the number of areolae per stria on the rapheless valve was set to 3, sometimes 2 areolae although in the accompanying table, 3-5 areolae are mentioned. Based on our results, and a more careful reanalysis of the illustrations in Witkowski et al. (2012), it is clear that the striae are composed of 2-5 rounded, sometimes slit-like areolae. Moreover, the populations observed on Iles Kerguelen and the other sub-Antarctic islands in the southern Indian Ocean, fine-tuned the morphometric data for this species. The observed length and width range in the freshwater and limno-terrestrial populations is larger than in the original description. Some raphe valves seem to lack one or two striae in the central area. The typical presence of 1-2 striae in the central area of $A$. sieminskae was used by Witkowski et al. (2012) as a discriminating feature to separate the species from A. minutissimum. It is clear that this feature should no longer be used. The separation of both taxa can also no longer be based on the denser striae near the apices as analysis of the Kützing type material of A. minutissimum (Novais et al. submitted) showed the presence of dense striae near the apices in the latter. Conspecificity of both taxa is however to be excluded but the separation of both taxa is therefore only possible based on the valve outline with more linear to linear-lanceolate valves (contrary to the typical lanceolate valves in A. minutissimum), the presence of clearly rostrate to capitate apices and differences in the number of areolae on the rapheless valve. In their analysis of the type of $A$. minutissimum, Novais et al. (submitted) show a rapheless valve having at least 5-6 rounded to weakly elongated areolae per stria whereas in the $A$. sieminskae valves shown in this paper, only 2-3(-4) rounded and one slit-like areola are shown. It is also clear that the raphe in $A$. sieminskae is usually more distinctly visible in LM than in A. minutissimum. Achnanthidium sieminskae shows some similarity to a few other (usually recently described) Achnanthidium taxa. Witkowski et al. (2012) compared their new species with $A$. jackii Rabenh. (Rabenhorst 1861) and A. lailae, although any confusion with the latter is entirely to be excluded based on valve outline, dimensions and stria structure. Achnanthidium ertzii Van de Vijver \& Lange-Bert. in Van de Vijver et al. (Van de Vijver et al. 2011a), described from Madeira, shows a similar elongated valve outline but has narrower valves with a lower number of areolae per stria (2-3 vs. 3-5 in A. sieminskae) making conspecificity highly unlikely. Achnanthidium maritimo-antarcticum, described in this paper, has comparable valve dimensions but a more linear-lanceolate valve outline (compared to the typical lanceolate outline in A. sieminskae), a lower number of areolae per stria (max. 3 ) and less protracted, rostrate to subcapitate apices. The correct taxonomic and morphological identity of other Achnanthidium taxa such as A. caledonicum (LangeBert.) J.E.Slate \& R.J.Stevenson (Slate \& Stevenson 2007) is at present unclear making a comparison between A. sieminskae and these taxa rather difficult. Achnanthidium caledonicum as it is currently known, is much longer and has clearly capitate apices.

\section{Conclusions}

The present paper highlights the need for thorough morphological revisions of the entire Antarctic freshwater and limno-terrestrial diatom flora applying a narrower species concept. The description of two new Achnanthidium taxa split off from Achnanthidium minutissimum s.l. improves our knowledge about the biogeography of species in this complex and allows their use in more precise ecological and biogeographical studies.

\section{Acknowledgements}

The authors wish to thank Niek J.M. Gremmen and Louis Beyens for the collection of samples on Heard Island, Prince Edward Islands and South Georgia. Sampling on Crozet and Kerguelen has been made possible thanks to the logistic and financial support of the French Polar Institute-Paul-Emile Victor 
VAN DE VIJVER B. \& KOPALOVÁ K., Achnanthidium minutissimum complex in the Antarctic

in the framework of the terrestrial program 136 (Marc Lebouvier \& Yves Frenot). Samples on Byers Peninsula were taken in the framework of the IPY-Limnopolar Project POL2006-06635 (Ministerio de Ciencia y Tecnología, Spain). The authors would also like to thank the members of expeditions to the Czech J.G. Mendel Antarctic Station for field support and assistance. K. Kopalová benefited from the GA UK grant nr. 394211. Part of the research was funded within the Belspo CCAMBIO project and an EU Synthesys grant to BVDV to visit the National History Museum in London, UK. Alex Ball, the staff of the EMMA laboratory and Eileen J. Cox at the Natural History Museum are thanked for their help with the scanning electron microscopy.

\section{References}

Bourrelly P. \& Manguin E. 1954. Contribution à la flore algale d'eau douce des Iles Kerguelen. Mémoires de l'Institut Scientifique de Madagascar, series B 5: 7-58.

Bukhtiyarova L. \& Round F.E. (1996). Revision of the genus Achnanthes sensu lato. Psammothidium, a new genus based on A. marginulatum. Diatom Research 11 (1): 1-30. http://dx.doi.org/10.1080/0269 249X.1996.9705361

Cleve P.T. \& Grunow A. 1880. Beiträge zur Kenntiss der Arctischen Diatomeen. Kongliga Svenska Vetenskaps-Akademiens Handlingar series 4, 17 (2), Kongliga Boktryckeriet, Stockholm.

Czarnecki D.B. 1994. The freshwater diatom culture collection at Loras College, Dubuque, Iowa. In: Kociolek J.P. (ed.) Proceedings of the $11^{\text {th }}$ International Diatom Symposium, San Francisco, $12-17$ August 1990. Memoirs of the California Academy of Sciences 17: 155-174. California Academy of Sciences, San Francisco.

Desmazières J.B.H.J. 1825. Plantes cryptogames du Nord de la France. Leleux, Lille.

Díaz Villanueva V. \& Maidana N. 1999. Diatoms (Bacillariophyceae) from Pulmarí lake (Neuquén, Argentina). Biologia (Bratislava) 54: 1-10.

Ector L. 2011. $1^{\text {st }}$ European Workshop on Diatom Taxonomy ( $1^{\text {st }}$ EWDT). Algological Studies 136/137: 1-4. http://dx.doi.org/10.1127/1864-1318/2011/0136-0001

Finlay B.J. \& Clarke K.J. 1999. Ubiquitous dispersal of microbial species. Nature 400: 828. http:// dx.doi.org/10.1038/23616

Hlúbiková D., Ector E. \& Hoffmann L. 2011. Examination of the type material of some diatom species related to Achnanthidium minutissimum (Kütz.) Czarn. (Bacillariophyceae). Algological Studies 136/137: 19-43. http://dx.doi.org/10.1127/1864-1318/2011/0136-0019

Ivanov P. \& Ector L. 2006. Achnanthidium temniskovae sp. nov., a new diatom from the Mesta River, Bulgaria. In: Ognjanova-Rumenova N. \& Manoylov K. (eds) Advances in Phycological Studies, Festschrift in Honour of Prof. Dobrina Temniskova-Topalova: 147-154. Pensoft Publishers \& University Publishing House, Sofia-Moscow.

Jones V.J., Juggins S. \& Ellis-Evans J.C. 1993. The relationship between water chemistry and surface sediment diatom assemblages in maritime Antarctic lakes. Antarctic Science 5: 339-348. http://dx.doi. org $/ 10.1017 / \mathrm{S} 095410209300046 \mathrm{X}$

Kellogg T.B. \& Kellogg D.E. 2002. Non-marine and littoral diatoms from Antarctic and subantarctic regions. Distribution and updated taxonomy. Diatom Monographs 1, A.R.G. Gantner Verlag KG, Vaduz.

Kobayashi H. 1997. Comparative studies among four linear-lanceolate Achnanthidium species (Bacillariophyceae) with curved terminal raphe endings. Nova Hedwigia 65: 147-163. 
Kopalová K., Veselá J., Elster J., Nedbalová L., Komárek J. \& Van de Vijver B. 2012. Benthic diatoms (Bacillariophyta) from seepages and streams on James Ross Island (NW Weddell Sea, Antarctica). Plant Ecology and Evolution 145: 190-208. http://dx.doi.org/10.5091/plecevo.2012.639

Kopalová K. \& Van de Vijver B. 2013. Structure and ecology of freshwater benthic diatom communities from Byers Peninsula, Livingston Island, South Shetland Islands. Antarctic Science 25 (2): 239-253. http://dx.doi.org/10.1017/S0954102012000764

Kopalová K., Nedbalová L., Nývlt D., Elster J. \& Van de Vijver B. 2013. Ecological assessment of the freshwater diatom communities from Ulu Peninsula (James Ross Island, NE Antarctic Peninsula). Polar Biology 36 (7): 933-948. http://dx.doi.org/10.1007/s00300-013-1317-5

Krammer K. \& Lange-Bertalot H. 1991. Bacillariophyceae 4. Teil: Achnanthaceae. Kritische Ergänzungen zu Navicula (Lineolatae) und Gomphonema. Gesamtliteraturverzeichnis Teil 1-4. In: Ettl H., Gärtner G., Gerloff J., Heynig H. \& Mollenhauer D. (eds) Süsswasserflora von Mitteleuropa 2/4: 1-437. Gustav Fischer, Stuttgart.

Kützing F.T. 1833. Synopsis Diatomacearum oder Versuch einer systematischen Zusammenstellung der Diatomeen. Linnaea 8 (5): 529-620. http://dx.doi.org/10.5962/bhl.title.65634

Kützing F.T. 1844. Die Kieselschaligen. Bacillarien oder Diatomeen. - W. Köhne, Nordhausen. http:// dx.doi.org/10.5962/bhl.title.64360

Lange-Bertalot H. \& Moser G. 1994. Brachysira. Monographie der Gattung. Bibliotheca Diatomologica 29, J. Cramer, Berlin - Stuttgart.

Le Cohu R. 2005. Révision des principales espèces dulçaquicoles d'Achnanthales (Bacillariophyta) des îles subantarctiques de Kerguelen. Algological Studies 116: 79-114. http://dx.doi.org/10.1127/1864$\underline{1318 / 2005 / 0116-0079}$

Maidana N.I. 1996. Diatomeas fosiles nuevas o poco conocidas para la Argentina: Lago Nahuel Huapi (Brazo Campanario), Prov. de Río Negro. Boletín de la Sociedad Argentina de Botanica 31: 177-191.

Mann D.G. 1989. The diatom genus Sellaphora: separation from Navicula. British Phycological Journal 24: 1-20. http://dx.doi.org/10.1080/00071618900650011

Mann D.G. 1999. The species concept in diatoms. Phycologia 38: 437-495. http://dx.doi.org/10.2216/ i0031-8884-38-6-437.1

Mcneill J., Barrie F.R., Buck W.R., Demoulin V., Greuter W., Hawksworth D.L., Herendeen P.S., Knapp S., Marhold K., Prado J., Prud'homme Van Reine W.F., Smith G.F., Wiersema J.H. \& Turland N.J. 2012. International Code of Nomenclature for algae, fungi, and plants (Melbourne Code). Regnum Vegetabile 154. Koeltz Scientific Books, Koenigstein.

Medlin L.K. \& Kaczmarska I. 2004. Evolution of the diatoms: V. Morphological and cytological support for the major clades and a taxonomic revision. Phycologia 43 (3): 245270. http://dx.doi.org/10.2216/ i0031-8884-43-3-245.1

Monnier O., Lange-Bertalot H., Hoffmann L. \& Ector L. 2007. The genera Achnanthidium Kützing and Psammothidium Bukhtiyarova et Round in the family Achnanthidiaceae (Bacillariophyceae): a reappraisal of the differential criteria. Cryptogamie, Algologie 28: 141-148.

Morales E.A., Ector L., Fernández E., Novais M.E., Hlúbiková D., Hamilton P.B., Blanco S., Vis M.L. \& Kociolek J.P. 2011. The genus Achnanthidium Kütz. (Achnanthales, Bacillariophyceae) in Bolivian streams: a report of taxa found in recent investigations. Algological Studies 136/137: 89-130. http:// dx.doi.org/10.1127/1864-1318/2011/0136-0089 
VAN DE VIJVER B. \& KOPALOVÁ K., Achnanthidium minutissimum complex in the Antarctic

Novais M.H., Hlúbiková D., Morais M., Hoffmann L. \& Ector L. 2011. Morphology and ecology of Achnanthidium caravelense (Bacillariophyceae), a new species from Portuguese rivers. Algological Studies 136/137: 131-150.

Novais M.H., Jüttner I., Van de Vijver B., Morais M.M., Hoffmann, L. \& Ector L. (submitted). Morphological diversity within the Achnanthidium minutissimum species complex (Bacillariophyta): comparison between type material and new Portuguese species. Phytotaxa (submitted)

Oppenheim D.R. 1994. Taxonomic studies of Achnanthes (Bacillariophyta) in freshwater maritime antarctic lakes. Canadian Journal of Botany 72: 1735-1748.

Peragallo M. 1903. Le Catalogue Général des Diatomées [issued in fascicles at various dates]. Vol. 2: 472-973. Clermont-Ferrand.

Ponader K.C. \& Potapova M.G. 2007. Diatoms from the genus Achnanthidium in flowing waters of the Appalachian Mountains (North America): Ecology, distribution and taxonomic notes. Limnologica 37: 227-241. http://dx.doi.org/10.1016/j.limno.2007.01.004

Potapova M.G. \& Ponader K.C. 2004. Two common North American diatoms, Achnanthidium rivulare sp. nov. and $A$. deflexum (Reimer) Kingston: morphology, ecology and comparison with related species. Diatom Research 19: 33-57. http://dx.doi.org/10.1080/0269249X.2004.9705606

Potapova M. 2006. Achnanthidium zhakovschikovii sp. nov. (Bacillariophyta) and related species from rivers of Northwestern Russia. Nova Hedwigia 82: 399-408. http://dx.doi.org/10.1127/0029$\underline{5035 / 2006 / 0082-0399}$

Potapova M. \& Hamilton P.B. 2007. Morphological and ecological variation within the Achnanthidium minutissimum (Bacillariophyceae) species complex. Journal of Phycology 43: 561-575. http://dx.doi. org/10.1111/j.1529-8817.2007.00332.x

Rabenhorst L. 1861. Die Algen Europa 's. Forsetzung der Algen Sachsens, resp. Mittel-Europa 's. Decades 101-102. E. Heinrich, Dresden.

Reichardt E. 2004. Eine bemerkenswerte Diatomeenassoziation in einem Quellhabitat im Grazer bergland, Österreich. Iconographia Diatomologica 13: 419-479.

Ross R., Cox E.J., Karayeva N.I., Mann D.G., Paddock T.B.B., Simonsen R. \& Sims P.A. 1979. An amended terminology for the siliceous components of the diatom cell. Nova Hedwigia Beiheft 64: 513533.

Round F.E., Crawford R.M. \& Mann D.G. 1990. The diatoms: Biology and Morphology of the genera. Cambridge University Press, Cambridge.

Rumrich U., Lange-Bertalot H. \& Rumrich M. 2000. Diatomeen der Anden. Von Venezuela bis Patagonien/Feuerland. Iconographia Diatomologica 9: 1-649.

Silva P.C. 1962. Classification of algae. In: Lewin R.A. (ed.) Physiology and biochemistry of algae: 827837. Academic Press, New York \& London.

Slate J.E. \& Stevenson R.J. 2007. The diatom flora of phosphorus-enriched and unenriched sites in an Everglades marsh. Diatom Research 22: 355-386. http://dx.doi.org/10.1080/0269249X.2007.9705721

Smith W. 1855. Notes of an excursion to the south of France and the Auvergne in search of Diatomaceae. Annals and Magazine of Natural History, series 2 15: 1-9.

Taylor J.C., Cocquyt C., Karthick B. \& Van de Vijver B. 2014. Analysis of the type of Achnanthes exigua Grunow (Bacillariophyta) with the description of a new Antarctic species. Fottea 14: 43-51. 
Tremarin P.I., Freire G.E., Bertolli L.M. \& Ludwig T.A.V. 2009. Catálogo das diatomáceas (OchrophytaDiatomae) continentais do estado do Paraná. Iheringia, Séries Botanica 64: 79-107.

Tyler P.A. 1996. Endemism in freshwater algae, with special reference to the Australian region. Hydrobiologia 336: 127-135. http://dx.doi.org/10.1007/BF00010826

Van de Vijver B. \& Beyens L. 1996. Freshwater diatom communities of the Strømness Bay area, South Georgia. Antarctic Science 8 (4): 359-368. http://dx.doi.org/10.1017/S0954102096000533

Van de Vijver B., Ledeganck P. \& Beyens L. 2001. Habitat preferences in freshwater diatom communities from sub-Antarctic Iles Kerguelen. Antarctic Science 13: 28-36. http://dx.doi.org/10.1017/ $\underline{\mathrm{S} 0954102001000050}$

Van de Vijver B., Frenot Y. \& Beyens L. 2002. Freshwater diatoms from Ile de la Possession (Crozet archipelago, Subantarctica). Bibliotheca Diatomologica 46: 1-412.

Van de Vijver B., Beyens L., Vincke S. \& Gremmen N. 2004. Moss-inhabiting diatom communities from Heard Island, sub-Antarctic. Polar Biology 27: 532-543. http://dx.doi.org/10.1007/s00300-004-0629-x

Van de Vijver B. \& Mataloni G. 2008. New and interesting species in the genus Luticola D.G.Mann (Bacillariophyta) from Deception Island (South Shetland Islands). Phycologia 45: 451-467. http:// dx.doi.org/10.2216/07-67.1

Van de Vijver B., Gremmen N. \& Smith V. 2008. Diatom communities from the sub-Antarctic Prince Edward Islands: diversity and distribution patterns. Polar Biology 31: 795-808. http://dx.doi.org/10.1007/ $\underline{\mathrm{s} 00300-008-0418-\mathrm{Z}}$

Van de Vijver B., Mataloni G., Stanish L. \& Spaulding S.A. 2010. New and interesting species of the genus Muelleria (Bacillariophyta) from the Antarctic region and South Africa. Phycologia 49 (1): 22-41. http://dx.doi.org/10.2216/09-27.1

Van de Vijver B., Jarlman A., Lange-Bertalot H., Mertens A., de Haan M., Ector L. 2011a. Four new Achnanthidium species (Bacillariophyceae). Algological studies 136/137: 193-210.

Van de Vijver B., Ector L., Beltrami M.E., de Haan M., Falasco E., Hlúbiková D., Jarlman A., Kelly M., Novais M.H. \& Wojtal A. 2011b. A critical analysis of the type material of Achnanthidium lineare W.Sm. (Bacillariophyceae). Algological Studies 136/137: 167-192.

Van de Vijver B., Zidarova R. \& de Haan M. 2011c. Four new Luticola taxa (Bacillariophyta) from the South Shetland Islands and James Ross Island (Maritime Antarctic Region). Nova Hedwigia 92: 137158. http://dx.doi.org/10.1127/0029-5035/2011/0092-0137

Van de Vijver B., Zidarova R., Sterken M., Verleyen E., de Haan M., Vyverman W., Hinz F. \& Sabbe K. 2011d. Revision of the genus Navicula s.s. (Bacillariophyceae) in inland water of the Sub-Antarctic and Antarctic with the description of 5 new species. Phycologia 50: 281-297. http://dx.doi.org/10.2216/10$\underline{49.1}$

Van der Werff A. 1955. A new method of concentrating and cleaning diatoms and other organisms. Verhandlungen Internationalen Vereinigung für Theoretische und Angewandte Limnologie 2: 276-277.

Witkowski A., Kulikovskiy M. \& Riaux-Gobin C. 2012. Achnanthidium sieminskae, a new diatom species from the Kerguelen Archipelago (Austral Islands). In: Wolowski K., Kaczmarska I., Ehreman J.M. \& Wojtal A.Z. (eds) Current advances in algal taxonomy and its applications: phylogenetic, ecological and applied perspective: 61-68. Polish Academy of Sciences, Kraków.

Wojtal A.Z., Ector L., Van de Vijver B., Morales E.A., Blanco S., Piatek J. \& Smieja A. 2011. The Achnanthidium minutissimum complex (Bacillariophyceae) in southern Poland. Algological Studies 136/137: 211-238. 
VAN DE VIJVER B. \& KOPALOVÁ K., Achnanthidium minutissimum complex in the Antarctic

Zidarova R., Van de Vijver B., Mataloni G., Kopalová K. \& Nedbalová L. 2009. Four new freshwater diatom species (Bacillariophyceae) from Antarctica. Cryptogamie, Algologie 30: 295-310.

Zidarova R. Van de Vijver B., Quesada A. \& de Haan M. 2010. Revision of the genus Hantzschia (Bacillariophyceae) on Livingston Island (South Shetland Islands, Southern Atlantic Ocean). Plant Ecology and Evolution 143: 318-333. http://dx.doi.org/10.5091/plecevo.2010.402

Zidarova R., Kopalová K., Van de Vijver B. 2012. The genus Pinnularia (Bacillariophyta) excluding the section Distantes on Livingston Island (South Shetland Islands) with the description of twelve new taxa. Phytotaxa 44: 11-37.

Manuscript received: 4 November 2013

Manuscript accepted: 26 February 2014

Published on: 7 April 2014

Topic editor: Thomas Janssen

Desk editor: Natacha Beau

Printed versions of all papers are also deposited in the libraries of the institutes that are members of the EJT consortium: Muséum National d'Histoire Naturelle, Paris, France; Botanic Garden Meise, Belgium; Royal Museum for Central Africa, Tervuren, Belgium; Natural History Museum, London, United Kingdom; Royal Belgian Institute of Natural Sciences, Brussels, Belgium; Natural history Museum of Denmark, Copenhagen, Denmark. 